\title{
Haplotypes of the bovine IgG2 heavy gamma chain in tick-resistant and tick-susceptible breeds of cattle
}

\author{
Wanessa Araújo Carvalho • Patricia Ianella • Frederico G. C. Arnoldi • \\ Alexandre Rodrigues Caetano • Sandra Regina Maruyama • \\ Beatriz Rossetti Ferreira • Luís Henrique Andreucci Conti • \\ Marcia Ramos Monteiro da Silva • José Otavio F. Paula • \\ Antonio Augusto Mendes Maia • Isabel K. Ferreira de Miranda Santos
}

Received: 7 October 2010 / Accepted: 23 January 2011 / Published online: 8 February 2011

(C) The Author(s) 2011. This article is published with open access at Springerlink.com

\begin{abstract}
Bovines present contrasting, heritable phenotypes of infestations with the cattle tick, Rhipicephalus (Boophilus) microplus. Tick salivary glands produce IgGbinding proteins (IGBPs) as a mechanism for escaping from host antibodies that these ectoparasites ingest during blood meals. Allotypes that occur in the constant region of $\operatorname{IgG}$ may differ in their capacity to bind with tick IGBPs; this may be reflected by the distribution of distinct allotypes
\end{abstract}

Wanessa Araújo Carvalho and Patricia Ianella contributed equally to this work.

Electronic supplementary material The online version of this article (doi:10.1007/s00251-011-0515-y) contains supplementary material, which is available to authorized users.

W. A. Carvalho · F. G. C. Arnoldi · S. R. Maruyama •

I. K. F. de Miranda Santos $(\bowtie)$

Department of Biochemistry and Immunology,

Ribeirão Preto School of Medicine, University of São Paulo,

Av. Bandeirantes 3900,

Ribeirão Preto, SP 14049-900, Brazil

e-mail: imsantos@fmrp.usp.br

P. Ianella • A. R. Caetano • I. K. F. de Miranda Santos

Center for Genetic Resources and Biotechnology,

Brazilian Enterprise for Agricultural Research,

Brasília, DF 70770-900, Brazil

\section{B. R. Ferreira}

Departament of Maternal and Child Nursing and Public Health, Ribeirão Preto School of Nursing, University of São Paulo,

Ribeirão Preto, SP 14049-900, Brazil

L. H. Andreucci Conti • M. R. M. da Silva - J. O. F. Paula •

A. A. M. Maia

Department of Basic Sciences, Faculty of Animal Science and Food Engineering, São Paulo University,

Pirassununga, SP 13635-900, Brazil according to phenotypes of tick infestations. In order to test this hypothesis, we investigated the frequency of haplotypes of bovine IgG2 among tick-resistant and ticksusceptible breeds of bovines. Sequencing of the gene coding for the heavy chain of IgG2 from 114 tick-resistant (Bos taurus indicus, Nelore breed) and tick-susceptible (B. t. taurus, Holstein breed) bovines revealed SNPs that generated 13 different haplotypes, of which 11 were novel and 5 were exclusive of Holstein and 3 of Nelore breeds. Alignment and modeling of coded haplotypes for hinge regions of the bovine IgG2 showed that they differ in the distribution of polar and hydrophobic amino acids and in shape according to the distribution of these amino acids. We also found that there was an association between genotypes of the constant region of the IgG2 heavy chain with phenotypes of tick infestations. These findings open the possibility of investigating if certain IgG allotypes hinder the function of tick IGBPs. If so, they may be markers for breeding for resistance against tick infestations.

Keywords Bovine IgG2 · Allotypes · Haplotypes · Hinge region $\cdot$ Rhipicephalus (Boophilus) microplus

\section{Introduction}

Allotypic markers of $\operatorname{IgG}$ constant heavy chains are encoded by Mendelian co-dominant alleles and have important immunological functions (Grubb 1994). Accordingly, IgG allotypes have been associated with resistance to infections with different microbes (Kacskovics, Wittum, Butler et al. 1995; Corbeil, Gogolewski, Kacskovics et al. 1997; Jönsson, Oxelius, Truedsson et al. 2006; Skattum, Gullstrand, Holmström et al. 2008; Pandey, Namboodiri, 
Luo et al. 2008; Giha, Nasr, Iriemenam et al. 2009). There is only one study that documents associations between IgG allotypes and the outcome of infestations with a metazoan parasite, Onchocerca volvulus, (Pandey, Elson, Sutherland et al. 1995). Associations between IgG allotypes and outcomes of infestations with hematophagous ectoparasites have never been examined. Hematophagy is an ancient selective pressure on the immune system having evolved when animals with a closed circulatory system appeared (Ribeiro 1995). Immunoglobulins are ingested by bloodfeeders in abundant quantities during infestations (Gudderra, Sonenshine, Apperson et al. 2002). Indeed, as an escape mechanism whereby they assist feeding females, male Ixodidae ticks secrete an IgG-binding protein in their immunomodulatory saliva (Wang and Nuttall 1995). Bos taurus indicus cattle are significantly more resistant than B. t. taurus to infestations with the cattle tick, Rhipicephalus (Boophilus) microplus, and crosses between these groups show varying levels of resistance (Blankenship, May and Hedgecock 2002) indicating a polygenic, heritable basis for the trait. Furthermore, different bovine breeds develop quantitatively different antibody responses against tick saliva (Kashino, Resende, Sacco et al. 2005). This suggests that among the genes involved in conferring resistance are those encoding immunoglobulins. A preliminary study showed that the distribution of serologically defined IgG2 allotypes (Butler, Navarro, and Heyermann 1994) differed significantly among taurine and indicine breeds (data not shown). In the present work, we describe new haplotypes of the bovine $\operatorname{IgG} 2$ heavy chain that were genotyped by resequencing a region between the $\mathrm{CH} 1$ and $\mathrm{CH} 3$ domains since it contains most of the variability resulting in different allotypes. This region was PCRamplified from individuals from indicine and taurine breeds. We examined if the frequencies of allo-haplotypes differ among two commercial cattle breeds that show contrasting phenotypes regarding tick infestations. We modeled the hinge regions of $\mathrm{IgG} 2$ molecules resulting from the different haplotypes. Finally, we looked for associations between genotypes of the constant region of the IgG2 heavy chain and infestation phenotypes.

This study was approved by the local ethics committee. Genomic DNA was isolated with Puregene kit (Gentra Systems Inc., Minneapolis, MN) from blood samples from tick-resistant $(n=47 ; B$. t. indicus, Nelore breed) and ticksusceptible ( $n=67 ;$ B. t. taurus, Holstein breed) cattle. A fragment from a region between the $\mathrm{CH} 3$ domain and the hinge region of $\operatorname{IgG} 2$ heavy chain gene was amplified by PCR with specific primers (5'CGGGGTGC TGTGAACCA3' and 5'GTTCCCTCACGCCTAATGG3'), treated with ExoSAP-IT (Amershan, Piscataway, NJ) and sequenced with BigDye terminator chemistry (Applied Biosystems, Carlsbad, CA). DNA sequences were analyzed using Phred/Phrap/Consed (Ewing, Hillier, Wendl et al. 1998; Ewing and Green 1998) and PolyPhred (Nickerson, Tobe, and Taylor 1997) tools and nineteen single nucleotide polymorphisms (SNPs) were identified (Table 1). Individual SNP frequencies, estimated by Microsatellite Toolkit (Park 2001), demonstrated that ten SNPs showed breedspecific alleles $(P<0.001$, Supplemental Table). Haplotypic frequencies of the $\operatorname{IgG} 2$ exon fragment, calculated using Arlequin (ELB algorithm; Excoffier, Laval and Schneider 2005), revealed 13 different IgG2 haplotypes, of which 8 were exclusive of taurines, and 2 of indicines (Table 1). RXC software (Miller 1997) demonstrated a highly significant difference in the distribution of haplotypes between taurines and indicines $(P=0.000010 \pm 0.000001$, Metropolis algorithm). The $\operatorname{IgG} \gamma 2^{\mathrm{a}}$ allotype was significantly more frequent in taurine animals $(P<0.0001)$, while $\operatorname{IgG} \gamma 2^{\mathrm{b}}$ was significantly more frequent in indicine animals $(P<0.0001$; Table 1$)$.

IgG-binding proteins (IGBPs) are a common escape mechanism among pathogens against which antibodies constitute the main effector mechanisms (De MirandaSantos and Campos-Neto 1981). Certain IgG allotypes are bound less efficiently by IGBPs secreted by Staphylococcus aureus (Van Loghem, Frangione, Recht, and Franklin EC 1982), Haemophilus somnus (Corbeil, Gogolewski, Kacskovics et al. 1997; Bastida-Corcuera, Nielsen, and Corbeil 1999a), and hepatitis C virus Namboodiri, Budkowska, Nietert, and Pandey 2007 and are associated with a more favorable outcome to infection with the latter pathogens. We show herein that tick IGBPs are abundantly expressed in tick salivary glands. Annotation of a nonnormalized cDNA library of $R$. microplus male salivary glands using BLAST results showed that two contigs contained more transcripts and sequences coding for proteins similar to IGBPs than expected from a random distribution, as evaluated with the $\chi^{2}$ test (Table 2). Tick IGBPs may differ in their ability to bind to IgG allotypes compromising the tick's capacity to modulate host-antibody responses. In order to begin testing these hypotheses, we aligned coded haplotypes of the bovine $\operatorname{IgG} 2$ hinge region. Figure 1a shows that haplotypes of the bovine IgG2 hinge region differ in the distribution of polar and hydrophobic amino acids.

We then modeled coded hinge regions of the haplotypes. In silico models were built with Swiss-model repository software (Swiss Institute of Bioinformatics \& the Biozentrum, University of Basel, Switzerland) based on an X-ray diffraction of a human IgG1 (1HZH, Protein Data Bank). PyMOL Molecular Graphics System (Schrödinger Corporation, NY, USA) was employed to overlay human IgG1 with the coded haplotypes for bovine $\operatorname{IgG} 2$ hinge region obtained with the modeling (Fig. 1b, c). This resulted in five groups of molecules that differed in shape in the hinge region 
Table $1 \mathrm{IgG} 2$ haplotype frequencies in genetically tick-resistant (Nelore, Bos taurus indicus) and tick-susceptible (Holstein, Bos taurus taurus) breeds of cattle

\begin{tabular}{|c|c|c|c|c|c|}
\hline \multirow[t]{2}{*}{ Gene } & \multirow[t]{2}{*}{ Haplotype $^{\mathrm{a}}$} & \multirow[t]{2}{*}{ Amino acid residues in hinge region ${ }^{\mathrm{b}}$} & \multicolumn{2}{|c|}{$\%$ Haplotype frequency } & \multirow{2}{*}{$\begin{array}{l}P \text { value } \\
\text { Fisher exact test }\end{array}$} \\
\hline & & & Nelore & Holstein & \\
\hline \multirow[t]{15}{*}{ IGHG2 } & {$[\mathrm{G} ; ? ; ? ; ? ; ?]^{\mathrm{c}}$} & - & 0 & 1.5 & 0.656 \\
\hline & {$[\mathrm{T} ; ? ; ? ; ? ; ?]^{\mathrm{c}}$} & - & 2.1 & 3.0 & 0.674 \\
\hline & {$[\mathrm{G} ; \mathrm{C} ; \mathrm{C} ; \mathrm{A} ; \mathrm{A}]$} & {$[\mathrm{S} ; \mathrm{P} ; \mathrm{N} ; \mathrm{H}]^{\mathrm{d}}$} & 14.9 & 59.8 & $<0.0001^{*}$ \\
\hline & [G;T;G;C;A] & {$[\mathrm{S} ; \mathrm{C} ; \mathrm{H} ; \mathrm{H}]$} & 0 & 0.8 & 0.855 \\
\hline & {$[\mathrm{G} ; \mathrm{C} ; \mathrm{G} ; \mathrm{A} ; \mathrm{A}]$} & {$[\mathrm{S} ; \mathrm{R} ; \mathrm{N} ; \mathrm{H}]$} & 0 & 9.8 & $0.009 *$ \\
\hline & {$[\mathrm{G} ; \mathrm{C} ; \mathrm{G} ; \mathrm{C} ; \mathrm{A}]$} & {$[\mathrm{S} ; \mathrm{R} ; \mathrm{H} ; \mathrm{H}]$} & 0 & 0.8 & 0.855 \\
\hline & {$[\mathrm{G} ; \mathrm{C} ; \mathrm{G} ; \mathrm{A} ; \mathrm{C}]$} & {$[\mathrm{S} ; \mathrm{R} ; \mathrm{N} ; \mathrm{P}]$} & 0 & 3 & 0.250 \\
\hline & [T;T;G;C;C] & {$[\mathrm{I} ; \mathrm{C} ; \mathrm{H} ; \mathrm{P}]^{\mathrm{e}}$} & 78.7 & 15.1 & $<0.001 *$ \\
\hline & {$[\mathrm{G} ; \mathrm{T} ; \mathrm{G} ; \mathrm{C} ; \mathrm{C}]$} & {$[\mathrm{S} ; \mathrm{C} ; \mathrm{H} ; \mathrm{P}]$} & 0 & 1.5 & 0.674 \\
\hline & {$[\mathrm{T} ; \mathrm{C} ; \mathrm{C} ; \mathrm{A} ; \mathrm{C}]$} & {$[\mathrm{I} ; \mathrm{P} ; \mathrm{N} ; \mathrm{P}]$} & 0 & 0.8 & 0.855 \\
\hline & {$[\mathrm{T} ; \mathrm{C} ; \mathrm{G} ; \mathrm{A} ; \mathrm{C}]$} & [I;R;N;P] & 0 & 0.8 & 0.855 \\
\hline & [T;C;G;C;C] & [I;R;H;P] & 2.1 & 2.3 & 0.686 \\
\hline & {$[\mathrm{G} ; \mathrm{C} ; \mathrm{G} ; \mathrm{C} ; \mathrm{C}]$} & [S;R;H;P] & 1.1 & 0 & 0.862 \\
\hline & [T;C;C;A;A] & {$[\mathrm{I} ; \mathrm{P} ; \mathrm{N} ; \mathrm{H}]$} & 1.1 & 0 & 0.862 \\
\hline & {$[\mathrm{T} ; \mathrm{C} ; \mathrm{G} ; \mathrm{A} ; \mathrm{A}]$} & {$[\mathrm{I} ; \mathrm{R} ; \mathrm{N} ; \mathrm{H}]$} & 0 & 0.8 & 0.855 \\
\hline
\end{tabular}

*Indicates that the $P$-value is significant after a Bonferroni correction, which was performed considering the number of haplotypes for the $I G H G 2$ gene

${ }^{a}$ Reference haplotype: bovine IgG2 exon B (X16702.1:g. [753G/T; 767C/T; 768C/G; 770A/C]

${ }^{\mathrm{b}}$ Amino acid residues at positions 219, 224, 225 and 228 resulting from SNPs identified at nucleotide positions 753, 767, 768, 770 and 780, respectively

${ }^{\mathrm{c}}$ Sample could not be genotyped at nucleotide positions 768,770 and 780

${ }^{\mathrm{d}}$ Haplotype corresponds to serologically defined allotype $\operatorname{IgG} \gamma 2^{\mathrm{a}}$

${ }^{\mathrm{e}}$ Haplotype corresponds to serologically defined allotype $\operatorname{IgG} \gamma 2^{\mathrm{b}}$

according to the presence of polar or hydrophobic amino acids (Figs. 1d-h). Figure 1d shows the template overlaid with the first group (G1) of allo-haplotypes that consists of allotype $\operatorname{IgG} \gamma 2^{\mathrm{a}}$ (grey), coding residues $\mathrm{S}, \mathrm{P}, \mathrm{N}$, and $\mathrm{H}$, and a haplotype (green) coding residues $\mathrm{S}, \mathrm{C}, \mathrm{H}$, and $\mathrm{H}$ at positions $219,224,225$, and 228 , respectively. These two haplotypes do not contain hydrophobic amino acids at positions 219 and 228 and are significantly more frequent or found only in taurine animals, respectively (Table 1). Figure 1e shows the template overlaid with the second group of haplotypes, which like those in group G1 do not contain hydrophobic amino acids at positions 219 and 228, but contain a positively charged arginine residue at position 224 . It contained one (yellow) coding residues $\mathrm{S}, \mathrm{R}, \mathrm{N}$, and $\mathrm{H}$ and another (pink) coding S, R, H, and $\mathrm{H}$ at positions 219, 224, 225 , and 228 , respectively. These haplotypes were found

Table 2 Distribution of differentially expressed transcripts coding for IgG-binding proteins in a non-normalized cDNA library ${ }^{\mathrm{a}}$ of male salivary glands of Rhipicephalus microplus ticks. The $\chi^{2}$ test was calculated using the average number of ESTs per contig $(2.65=3)$

\begin{tabular}{|c|c|c|c|c|c|}
\hline \multirow{2}{*}{$\frac{\text { Library }}{\text { MSGRm }^{\mathrm{b}}}$} & \multirow{2}{*}{$\begin{array}{l}\text { Total number of ESTs } \\
2,163\end{array}$} & \multicolumn{2}{|c|}{ Total number of contigs } & \multicolumn{2}{|c|}{ Average no. ESTs/contig } \\
\hline & & 817 & & 2.65 & \\
\hline Contig & Best match to NR protein database & $E$-value & Number of ESTs & Expected & $P$ value $\chi^{2}$ test \\
\hline \# 76 & $\begin{array}{l}\text { Immunoglobulin } \mathrm{G} \text { binding protein } \mathrm{C} \\
{[\text { Rhipicephalus appendiculatus }] \text { gi }|2352274|}\end{array}$ & $9 e-084$ & 27 & 15 & $<0.001$ \\
\hline \# 190 & $\begin{array}{l}\text { Immunoglobulin } \mathrm{G} \text { binding protein } \mathrm{B} \\
\text { [Rhipicephalus appendiculatus] gi }|2352272|\end{array}$ & $6 e-081$ & 25 & 14 & $<0.001$ \\
\hline
\end{tabular}

EST expressed sequence tag, NR non-redundant

${ }^{a}$ Details of library construction, sequencing, bioinformatic treatment, and contig annotation can be found in Maruyama et al. (2010)

${ }^{\mathrm{b}}$ Male salivary glands of Rhipicephalus microplus 


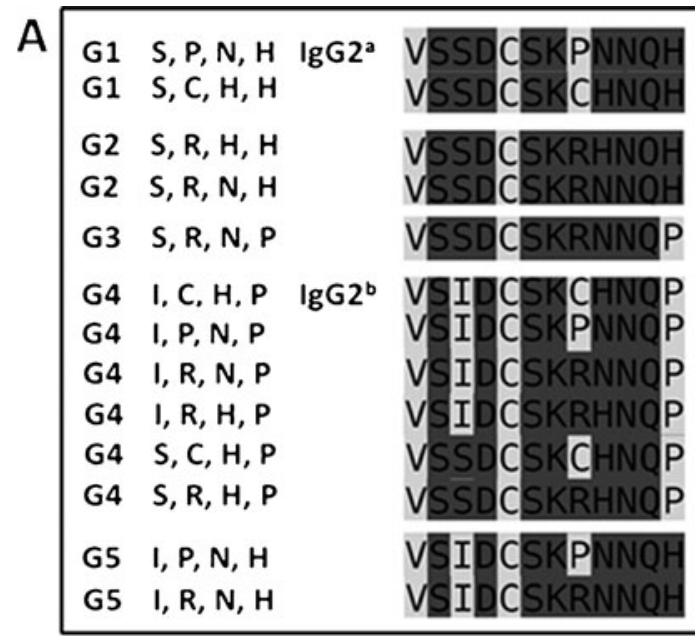
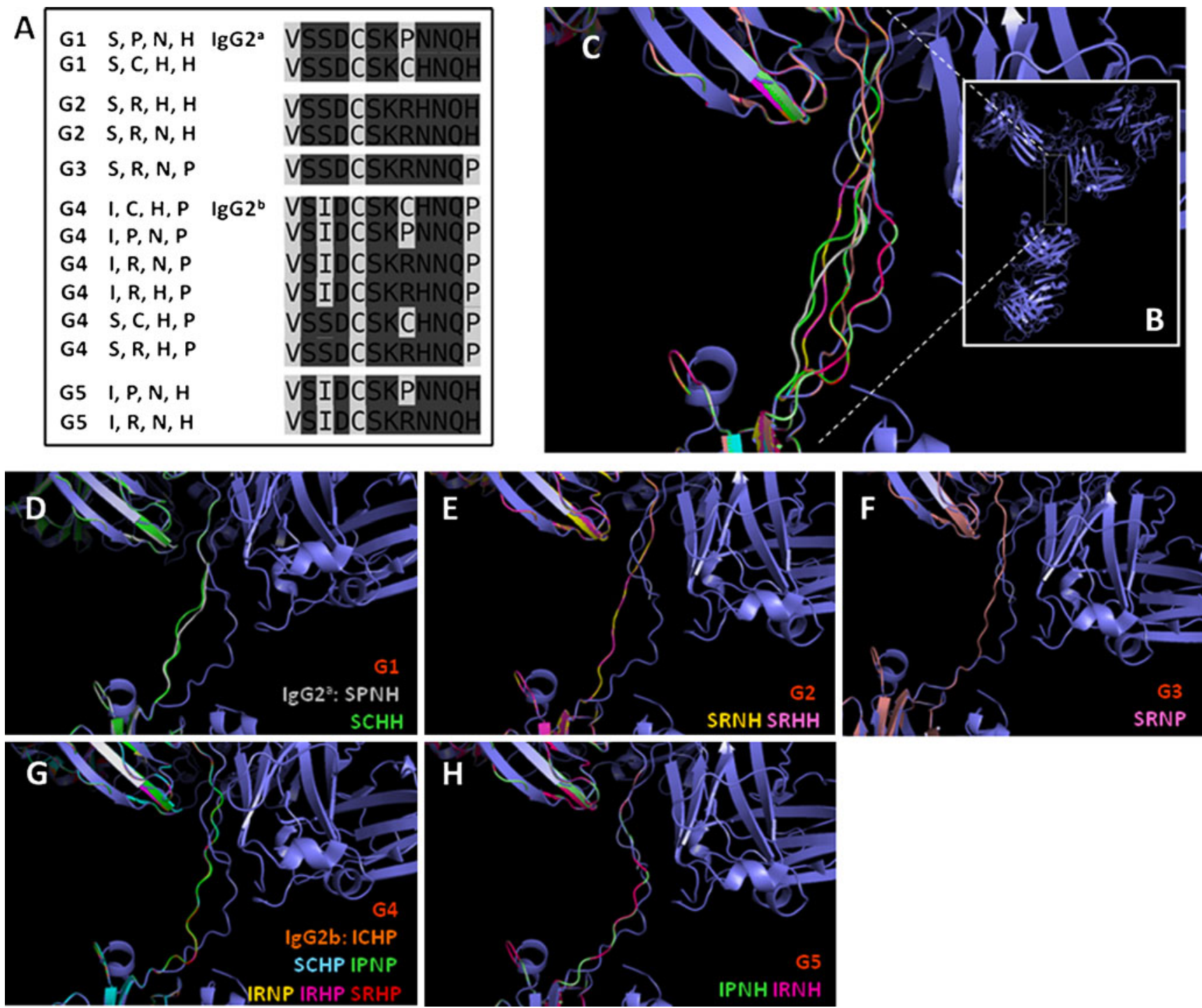

Fig. 1 Alignment and modeling of coded haplotypes of bovine IgG2 hinge region. a Alignment showing distribution of polar (dark grey boxes) and hydrophobic (light grey boxes) amino acids of coded haplotypes of the bovine IgG2 hinge region from positions 217 to 228 . b Template (X-ray diffraction of a human IgG1 [1HZH, Protein Data Bank]; blue in all figures) for modeling haplotypes of bovine IgG2 hinge region of heavy chain. White rectangle shows the hinge region amplified in Fig. 1c with the overlays. c Overlay of the hinge regions of all in silico models for bovine IgG2 haplotypes. $\mathbf{d}-\mathbf{h}$ Template overlaid with the five groups of haplotypes, G1-G5, and the respective amino acid residues coded at positions $219,224,225$, and 228 by each haplotype only in taurines at low frequencies (Table 1). Groups 3-5 contained a hydrophobic amino acid at position 219 or 228 or at both positions. The third group, shown in Fig. 1f, contained a single haplotype (pink) coding residues $\mathrm{S}, \mathrm{R}, \mathrm{N}$, and $\mathrm{P}$ at positions $219,224,225$, and 228, respectively. This haplotype was found only in taurines at low frequencies. The fourth group, shown in Fig. 1g, contained six haplotypes, the allo-haplotype $\operatorname{IgG} 2^{\mathrm{b}}$ (orange), more frequent in indicines and which codes residues $\mathrm{I}, \mathrm{C}, \mathrm{H}$, and $\mathrm{P}$, and haplotypes coding residues $\mathrm{S}, \mathrm{C}, \mathrm{H}$, and $\mathrm{P}$ (light blue), residues $\mathrm{I}, \mathrm{P}, \mathrm{N}$, and $\mathrm{P}$ (green), residues I, R, N, and P (yellow), residues I, R, $\mathrm{H}$, and $\mathrm{P}$ (magenta), and residues $\mathrm{S}, \mathrm{R}, \mathrm{H}$, and $\mathrm{P}$ (red) at positions 219, 224, 225, and 228, respectively. All of these haplotypes were found in both breeds of cattle (Table 1). Figure $1 \mathrm{~h}$ shows the template overlaid with the fifth group of haplotypes (G5), which contained one (green) coding residues I, P, N, and $\mathrm{H}$ and another (magenta) coding I, R, $\mathrm{N}$, and $\mathrm{H}$ at positions $219,224,225$, and 228 , respectively. These haplotypes were found in both breeds (Table 1). There are several potential consequences for the structural variations within the hinge regions of IgG2 allotypes. Although the role of the hinge region in complement activation and signaling through $\mathrm{Fc}$ receptors is disputed (Brekke, Michaelsen, and Sandlie 1995), it has an essential role in antigen binding (Oi, 
Vuong, Hardy et al. 1984; Michaelsen, Garred, and Aase 1991; Brekke, Michaelsen, and Sandlie 1995). While human $\mathrm{IgG} 2$ is a poor activator of complement, bovine $\mathrm{IgG} 2$, the subclass examined in this work and with which human $\operatorname{IgG} 2$ is not homologous, has a very small hinge region, but is a good complement activator depending on the allotype: bovine $\operatorname{IgG} 2^{\mathrm{b}}$ has more than double complement activity than bovine $\operatorname{IgG2}^{\mathrm{a}}$ (Bastida-Corcuera, Butler, Yahiro, and Corbeil 1999b). The role of structural modifications in the hinge region and $\operatorname{IgG}$ effector functions has not been examined by the few studies on associations between $\operatorname{IgG}$ allotypes and complement activity (Skattum, Gullstrand, Holmström et al. 2008; Jönsson, Oxelius, Truedsson et al. 2006) or Fc receptor dependent-effector mechanisms (Kumpel, Wiener, Urbaniak, and Bradley 1989), although one study did examine hinge flexibility of $\mathrm{IgG} 2$ allotypes with molecular plots (Bastida-Corcuera, Butler, Yahiro, and Corbeil 1999b).

We next examined if there was an association between genotypes of the constant region of the IgG2 heavy chain with phenotypes of tick infestations. Randomly selected bovines (Nelore $=9$; Holstein $=8$ ) were genotyped and managed together in a tick-infested pasture for 12 months; the numbers of female ticks larger than $4 \mathrm{~mm}$ were counted on one side of each animal 13 times at monthly intervals and the average number of ticks/year for each breed and group of genotypes was obtained. Interestingly, we found that taurine animals containing at least one allo-haplotype for $\operatorname{IgG} \gamma 2^{\mathrm{a}}$ presented significantly $(P=0.044)$ more feeding female ticks than the single taurine host homozygous for the $\operatorname{IgG} \gamma 2^{\mathrm{b}}$ allo-haplotype $(40.62 \pm 35.04$ and $24.15 \pm 24.01$ ticks/animal, respectively; Table 3). While indicine animals always presented significantly $(P<0,001)$ less feeding female ticks than taurine animals (an average of $3.45 \pm$ 5.22 versus $38.56 \pm 34.20$ ticks/animal, respectively; Table 3), the two heterozygous indicine animals also presented significantly $(P<0.001)$ more feeding ticks than individual homozygous for the $\operatorname{IgG} \gamma 2^{\mathrm{b}}$ allo-haplotype
$(6.73 \pm 6.60$ and $2.91 \pm 4.67$ feeding ticks/animal, respectively; Table 3). Due to allelic exclusion, both heavy chains of half of the antibodies produced by animals that are heterozygous for the $\operatorname{IgG} \gamma 2^{\mathrm{a}}$ allo-haplotype will bear this marker. Admitting that tick IGBPs bind this allo-haplotype more efficiently, our data suggests that a threshold of $50 \%$ IGBP-bound antibodies is still sufficient to allow ticks to complete a blood meal. It is also reasonable to suggest that this haplotype could constitute a marker for susceptibility to tick infestations.

In summary, we have described a PCR-based genotyping method and new haplotypes of the bovine IgG2 heavy chain. We observed differences in the polarity of amino acids of the hinge region of distinct haplotypes that may affect interactions of bovine $\mathrm{IgG} 2$ with host neonatal Fc receptors (FcRns) and tick IGBPs. Our results indicate that certain bovine allohaplotypes are associated with phenotypes of infestations with $R$. microplus. Interestingly, we have shown that after heavy exposure to R. microplus, the levels of anti-tick saliva IgG2 antibodies remain the same in indicine cattle and decrease in taurines even though these latter animals receive larger quantities of potentially antigenic tick saliva (Kashino, Resende, Sacco et al. 2005). This phenomenon may result from differing biological properties of IgG2 allotypes and merits further investigation. Levels of $\mathrm{IgG} 2$ are highly heritable in cattle (Mazengera, Kennedy, Burnside et al. 1985) and are also heritable in humans according to allotypes (Oxelius 1993). This may explain in part our previous findings. Additionally, FcRn which protect endocytosed IgG from degradation and prolong its half-life in the circulation of cattle (Cervenak and Kacskovics 2009) differ in their capacity to bind to allotypes of $\operatorname{IgG}$ (West and Bjorkman 2000). Indeed, the levels and catabolic rates of $\operatorname{IgG} 2$ differ according to their allotypes (Oxelius and Eibl 1996). FcRns may also differ in their capacity to bind to IgG coated with an IGBP. Taken together, our findings suggest that antibodies are crucial to control tick infestations and that allotypic variation may have important consequences for the host.

Table 3 Association of allo-haplotypes of the constant region of $\mathrm{IgG} 2$ heavy chain with phenotypes of tick infestations

\begin{tabular}{|c|c|c|c|c|}
\hline \multirow[t]{2}{*}{ Allo-haplotype } & \multicolumn{2}{|c|}{ No. allo-haplotypes/breed } & \multicolumn{2}{|c|}{ No. \pm SD of female ticks } \\
\hline & Nelore & Holstein & Nelore & Holstein \\
\hline SPNH/SPNH (IgG $\gamma 2^{\text {a }}$ homozygous) & 0 & 3 & - & $43.46 \pm 39.34$ \\
\hline SPNH/G4 haplotypes ( $\operatorname{IgG} \gamma 2^{\mathrm{a}}$ heterozygous) & 2 & 4 & $6.73 \pm 6.60$ & $38.48 \pm 31.65$ \\
\hline Total allo-haplotypes containing $\operatorname{IgG} \gamma 2^{\mathrm{a}}$ & 2 & 7 & $6.73 \pm 6.60$ & $40.62 \pm 35.04$ \\
\hline ICHP/ICHP (IgG $\gamma 2^{b}$ homozygous) & 7 & 1 & $2.91 \pm 4.67$ & $24.15 \pm 24.01$ \\
\hline$P$ value & $0.015^{\mathrm{a}}$ & & $<0.001^{\mathrm{b}}$ & $0.044^{\mathrm{b}}$ \\
\hline
\end{tabular}

${ }^{a}$ Comparison of the proportion of allo-haplotypes containing $\operatorname{IgG} \gamma 2^{\mathrm{a}}$ in two bovine breeds, Fisher Exact Test

${ }^{\mathrm{b}}$ Comparison of the median numbers of ticks between animals bearing allo-haplotypes containing $\operatorname{IgG} \gamma 2^{\mathrm{a}}$ and animals homozygous for IgG $\gamma 2^{\mathrm{b}}$ allohaplotypes, Mann-Whitney Rank Sum Test 
Acknowledgments We thank Dr. John Butler for furnishing allotyping sera and Celso T. Mendes Jr. for assistance in analyses. This work was supported by the Conselho Nacional de Desenvolvimento Científico e Tecnológico (grant no. 471388/); W.A.C. and S.R.M. received scholarships (no. 06/55825-0 and 2007/5937-4) from the Fundação de Amparo à Pesquisa do Estado de São Paulo.

Open Access This article is distributed under the terms of the Creative Commons Attribution Noncommercial License which permits any noncommercial use, distribution, and reproduction in any medium, provided the original author(s) and source are credited.

\section{References}

Bastida-Corcuera FD, Nielsen KH, Corbeil LB (1999a) Binding of bovine IgG2a and IgG2b allotypes to protein A, protein $\mathrm{G}$, and Haemophilus somnus IgBPs. Vet Immunol Immunopathol 18:143-149

Bastida-Corcuera FD, Butler JE, Yahiro S, Corbeil LB (1999b) Differential complement activation by bovine IgG2 allotypes. Vet Immunol Immunopathol 71:115-123

Blankenship SM, May B, Hedgecock D (2002) Evolution of a perfect simple sequence repeat locus in the context of its flanking sequence. Mol Biol Evol 19:1943-1951

Brekke OH, Michaelsen TE, Sandlie I (1995) The structural requirements for complement activation by IgG: does it hinge on the hinge? Immunol Today 16:85-90

Butler JE, Navarro P, Heyermann H (1994) Heterogeneity of bovine IgG2: comparative specificity of monoclonal and polyclonal capture antibodies for IgG2a (A1) and IgG2a (A2). Vet Immunol Immunopathol 40:119-133

Cervenak J, Kacskovics I (2009) The neonatal Fc receptor plays a crucial role in the metabolism of $\mathrm{IgG}$ in livestock animals. Vet Immunol Immunopathol 128:171-177

Corbeil LB, Gogolewski RP, Kacskovics I et al (1997) Bovine IgG2a antibodies to Haemophilus somnus and allotype expression. Can J Vet Res 61:207-213

De Miranda-Santos IKF, Campos-Neto A (1981) Receptor for immunoglobulin $\mathrm{Fc}$ on pathogenic but not on nonpathogenic protozoa of the Trypanosomatidae. J Exp Med 154:17321742

Ewing B, Green P (1998) Base-calling of automated sequencer traces using phred. II. error probabilities. Genome Res 8:186-194

Ewing B, Hillier L, Wendl MC et al (1998) Base-calling of automated sequencer traces using phred. I. accuracy assessment. Genome Res 8:175-185

Excoffier L, Laval G, Schneider S (2005) Arlequin (version 3.0): an integrated software package for population genetics data analysis. Evol Bioinform Online 1:47-50

Giha HA, Nasr A, Iriemenam NC et al (2009) Antigen-specific influence of $\mathrm{GM} / \mathrm{KM}$ allotypes on $\operatorname{IgG}$ isotypes and association of GM allotypes with susceptibility to Plasmodium falciparum malaria. Malar J 8:306

Grubb RE (1994) Human immunoglobulin allotypes and Mendelian polymorphism of the human immunoglobulin genes. In: Oss CJ Jr, Regenmortel MHV Jr (eds) Immunochemistry. Marcel Dekker, New York, pp 47-68

Gudderra NP, Sonenshine DE, Apperson CS et al (2002) Hemolymph proteins in ticks. J Insect Physiol 48:269-278

Jönsson G, Oxelius VA, Truedsson L et al (2006) Homozygosity for the IgG2 subclass allotype $\mathrm{G} 2 \mathrm{M}(\mathrm{n})$ protects against severe infection in hereditary C2 deficiency. J Immunol 177:722728
Kacskovics I, Wittum TE, Butler JE et al (1995) The heterogeneity of bovine IgG2. VII. the phenotypic distribution of the A1 and A2 allotypes of $\mathrm{IgG} 2 \mathrm{a}$ among beef cows with known clinical history. Vet Immunol Immunopathol 48:89-96

Kashino SS, Resende J, Sacco AM et al (2005) Boophilus microplus: the pattern of bovine immunoglobulin isotype responses to high and low tick infestations. Exp Parasitol 110:12-21

Kumpel BM, Wiener E, Urbaniak SJ, Bradley BA (1989) Human monoclonal anti-D antibodies. II. the relationship between IgG subclass, $\mathrm{Gm}$ allotype and $\mathrm{Fc}$ mediated function. Br J Haematol $71: 415-420$

Maruyama SR, Anatriello E, Anderson JM et al (2010) The expression of genes coding for distinct types of glycine-rich proteins varies according to the biology of three metastriate ticks, Rhipicephalus (Boophilus) microplus, Rhipicephalus sanguineus and Amblyomma cajennense. BMC Genomics 11:363

Mazengera KE, Kennedy BW, Burnside EB et al (1985) Genetic parameters of bovine serum immunoglobulins. J Dairy Sci 68:2309-2314

Michaelsen TE, Garred P, Aase A (1991) Human IgG subclass pattern of inducing complement-mediated cytolysis depends on antigen concentration and to a lesser extent on epitope patchiness, antibody affinity and complement concentration. Eur J Immunol 21:11-16

Miller MP (1997) R x C: A program for the analysis of contingency tables via the metropolis algorithm. http://www.marksgeneticsoftware.net/ rxc.htm. Accessed on 10 July 2010

Namboodiri AM, Budkowska A, Nietert PJ, Pandey JP (2007) Fc $\gamma$ receptor-like hepatitis $\mathrm{C}$ virus core protein binds differentially to IgG of discordant Fc (GM) genotypes. Mol Immunol 4:38053808

Nickerson DA, Tobe VO, Taylor SL (1997) PolyPhred: automating the detection and genotyping of single nucleotide substitutions using fluorescence-based resequencing. Nucleic Acids Res $15: 2745-2751$

Oi VT, Vuong TM, Hardy R et al (1984) Correlation between segmental flexibility and effector function of antibodies. Nature 307:136-140

Oxelius VA (1993) Serum IgG and IgG subclass contents in different Gm phenotypes. Scand J Immunol 37:149-153

Oxelius VA, Eibl MM (1996) Different Gm allotype amounts in human intravenous immunoglobulin (IVIG) preparations; survival of foreign $\mathrm{Gm}$ allotypes in immunodeficient patients. Clin Exp Immunol 106:203-207

Pandey JP, Elson LH, Sutherland SE et al (1995) Immunoglobulin $\kappa$ chain allotypes $(\mathrm{Km})$ in onchocerciasis. J Clin Invest 96:2732-2734

Pandey JP, Namboodiri AM, Luo Y et al (2008) Genetic markers of IgG influence the outcome of infection with hepatitis $\mathrm{C}$ virus. $\mathrm{J}$ Infect Dis 198:1334-1336

Park SDE (2001) Trypanotolerance in West African cattle and the population genetic effects of selection. Ph.D. thesis, University of Dublin

Ribeiro JM (1995) Blood-feeding arthropods: live syringes or invertebrate pharmacologists? Infect Agents Dis 4:143-152

Skattum L, Gullstrand B, Holmström E et al (2008) Serum bactericidal activity against Neisseria meningitidis in patients with C3 nephritic factors is dependent on IgG allotypes. Clin Immunol 129:123-131

Van Loghem E, Recht FB, Franklin EC B (1982) Staphylococcal protein $\mathrm{A}$ and human $\operatorname{IgG}$ subclasses and allotypes. Scand $\mathrm{J}$ Immunol 15:275-278

Wang H, Nuttall PA (1995) Immunoglobulin-G binding proteins in the ixodid ticks, Rhipicephalus appendiculatus, Amblyomma variegatum and Ixodes hexagonus. Parasitol 111:161-165

West AP Jr, Bjorkman PJ (2000) Crystal structure and immunoglobulin $\mathrm{G}$ binding properties of the human major histocompatibility complex-related Fc receptor. Biochemistry 39(32):9698-9708 